\title{
LOCAL GOVERNANCE AND TERRITORIAL DEVELOPMENT ON THE BASIS OF GIS
}

\author{
Iryna Lytvynchuk ${ }^{1}$, Oleh Skydan², Olha Ivaniuk ${ }^{3}$ \\ ${ }^{1}$ Dr.Sc., Professor, Polissia National University, Staryi Blvd. 7, Zhytomyr, Ukraine, 10008. \\ Phone number +380671941192; Email Address Iryna.lytvynchuk@ukr.net \\ ${ }^{2}$ Dr.Sc., Professor, Polissia National University, Staryi Blvd. 7, Zhytomyr, Ukraine, 10008. \\ Phone number+380987174837; Email Address skydanoleg@ukr.net \\ ${ }^{3}$ PhD, Associate Professor, Polissia National University, Staryi Blvd. 7, Zhytomyr, Ukraine, 10008. \\ Phone number+380979897215; Email Address olha.ivanuk@gmail.com
}

Received 2202 2020; Accepted 19122020

\begin{abstract}
The paper is contributing to the development concept through highlighting the issue of implementing a brandnew territorial management system based on GIS technology into the regional public governance of developing country (on the example of Zhytomyr oblast of Ukraine as a leader of decentralization processes in the state according the official statistics of forming the amalgamated communities). Three basic methods were used: monographic method - to identify the peculiarities of the GIS activities of regional government entities; comparative studies and benchmarking - to compare GIS managing models performed in the world and find the best relevant practices; project management analysis - to prepare solution for creating pilot model as a full turnkey intellectual product (ready for dissemination project application which include logical-structural matrix of project goals and results, stakeholders analysis, timing for activities, indicators for evaluation, budget etc). Project application is completed with an evaluation of the Zhytomyr regional geoportal, implemented on its basement. In particular, there have been analyzed geoportal functions, their impact from economic and social benefits point, existing problems related to the project implementation process, benefits and prospects for future activities. It is proved that performed model will allow to create more effective than already existing mechanism of public administration at the region; to develop algorithms for interaction between public authorities and communities, to enhance the process of decentralization and territorial development
\end{abstract}

Keywords: amalgamated communities, geographic information system technologies, decentralization reform, local governance, regional development.

JEL Codes: H70; N90; O21; O33; R58.

\section{Introduction}

Decentralization reform in Ukraine has opened the door for a number of initiatives and opportunities for the local communities but has exacerbated the risks of local governance capacity due to the lack of a common information area for horizontal and vertical integration of local governance systems. According to the regional perspective plans of territorial formation, approved by the Ukrainian government, upon completion of the decentralization reform, 9709 territorial communities and 1359 amalgamated communities should be formed in the territory of Ukraine instead of 465 districts. It will fundamentally change the principles of state zoning and will increase almost 3 times the number of regional governance entities at different levels of the hierarchy.

The changes mentioned above (under conditions of the lack of effective and successful coordination practices inside the newly formed public administration system) create a number of problems, which influence on the sustainability of territorial development and by this on the competitiveness of Ukraine on the world arena.

Copyright (C) 2020. Published by Vytautas Magnus University. This is an open access article distributed under the terms of the Creative Commons Attribution Non-Commercial 4.0 (CC BY-NC 4.0) license, which permits unrestricted use, distribution, and reproduction in any medium provided the original author and source are credited. The material cannot be used for commercial purposes. 
In particular, we should definitely mention: 1) the lack of mechanisms for ensuring appropriate communication in the management vertical (taking into account the peculiarities of the regions cross-border status, environmental loading, economic capacity etc.); 2) the lack of full information support for the activities of the local authorities regarding the available assets and potentials of the communities (absence of complete property inventory and demographic information; no disaggregation of official statistic data to the community level etc.); 3) resource conflicts between communities (about land, finance, infrastructure); 4) human resources' problem (reduction of a large part of the state employees due the government recruitment reform). The bright evidence of those problems is the miserable number of the inter-municipal cooperation agreements in Ukraine (509 cases for 20152019 years and more than $60 \%$ of them belong to the 5 regions only) (Decentralization..., 2019; Decentralization..., 2020).

At the same time Geographic Information Systems all over the world have become one of the most effective and fast tools for decision-making in urban and rural regional planning for local authorities. Taking into account the government's digitalization initiatives and tendencies of national geospatial data infrastructure development, we suppose to solve the problems of local management in Ukraine by creating and applying at the regional level a set of geoinformation systems tools (geoportals and inter-portal systems) that will optimize communication among communities, among different regional authorities, and between communities and regional authorities to improve territorial governance. We make attempt to conduct case study about what recourses randomly selected region in Ukraine needs to build a GIS-system of efficient, transparent, inclusive, multi-level territorial governance; as well as to organize effective interaction between public authorities, businesses and civil society organizations in order to meet the strategic priorities of community and territorial development with more sophistication than traditional manual methods do.

The issue of the local development management in the context of geospatial systems was investigated in a theoretical and practical way both. Since the end of the XX century some researchers made attempt to build fundamental concept and vision of the problem on the basement of latest 50 years of investigations all over the world. In particular, Heywood et al. (1998) identified general approaches of implementing a GIS into the governance. Elwood and Leitner (1998) contributed to a better understanding of the problems, which communities face in accessing and using GIS-based data sources and technology. The same questions were developed scientifically by Talen (2000), who explored the advantage of using GIS in participatory planning activities from the viewpoint of local, especially rural, preferences. Nedović-Budić (2000) investigated integration of geospatial technologies with urban models.

Carver, Evans, Kingston, and Turton (2001) discussed the problems associated with public participation in the light of recent development of the cyberdemocracy. Sieber (2006) first presented the concept of public participation geographic information systems as a tool to broaden public involvement in policymaking as well as to promote the goals of nongovernmental organizations, grassroots groups, and community-based organizations. Drummond and French (2008) outlined important changes in geospatial technology to initiate a discussion of how the planning can best respond to the future challenges and opportunities for development. The same ideas were supported by Ramsey (2008), who examined the aspects of depoliticization of GIS to support the collaborative planning. Thompson (2016) focused on the modern model of citizen participation and studied issues how and why citizen science influenced the progression of participation GIS. Petch (2019) proved that GIS projects have socio-organisational contexts, which must be taken into account in local development projects.

Unlike apologists of the pure theory, many authors focused their attention on the success stories concerning GIS implementation efforts in a practical point of view. For instance, Somers (1991) provided an overview of GIS activities of local government in the USA, identifies some significant emerging models, trends and issues. Campbell (1994) presented results of the findings of twelve case studies which were undertaken by British local government. Budic (1994) explored how the new technology affects planning and whether it meets the expectations of the planning agencies using it 
on the example of four southeastern states of the USA. Ceccato and Snickars (2000) represented the empirical findings from using GIS in a quality-of-life study in conjunction with an urban renewal project of a residential area in Stockholm County, Sweden. Yearley, Cinderby, Forrester, Bailey and Rosen (2003) reported on participatory modelling decisions, developed in ESRC-funded work in the UK. Radil and Jiao (2016) contributed to the debates about the evaluating participatory geographic information systems by analyzing the recent participatory planning project undertaken in Muncie, Indiana. Kim, Gwak and Koh (2019) analyzed the local spatial data infrastructure for Seoul Metropolitan Government in comparison with the relevant cases of the USA and Germany.

Special segment in the modern science (on the contest of the paper topic) we give to authors who investigate the experience of developing countries. In particular, Odendaal (2003) raised awareness of spatial issues that impact local governance on defined municipal areas in Brisbane, Australia and Durban, South Africa. Dekolo and George (2004) highlighted the activities and initiatives of Lagos state planning information center for regional development. Patterson and Hoalst-Pullen (2009) looked at the use of GIS for developing the Cobb County, Georgia and highlighted models used by the County for green space preservation and industrial assessment.

Baud et al. (2016) presented case studies in six medium-sized cities in India, South Africa, Brazil, and Peru, linking to discussions on how knowledge construction and circulation, transformed through digitization and spatialization, can improve competences in local government, make urban planning more knowledge-based, and provide greater recognition of citizens' knowledge. Medolińska, Gołębiowska, and Karsznia (2017) presented the process of designing and developing a GIS portal for the local community in a small town in Poland, Sokółka. Eria and McMaster (2017) showed the process of adoption of GIS by institutions in Uganda from the viewpoint of diffusion theory. Moura and Procopiuck (2020) provide a view of the geographic distribution of basic sanitation e-services offered in Parana, Brazil.

A number of publications were prepared by official companies and institutions to help local governments at planning and analysis. Publications of ESRI (GIS Solutions..., 2006; A Guide for Smart Communities..., 2018) described the case studies of Charleston, South Carolina (usage satellite imagery for studying the rate of development in the metropolitan Charleston area); Madrid, Spain (implementing ESRI's ArcSDE technologies into General urban management plan for expanding a city and its infrastructure and for protecting historical areas); Sumter, South Carolina (implementing zoning analysis into the public petitions filed with a spatial technology); Richmond, Virginia (adopting GIS for the land use administration). Federal Geographic Data Committee (Best Practices..., 2011) gives some common elements that contribute to a foundation on which successful local government geospatial programs are built. GIS Geography (1000 GIS Applications \& Users..., 2016) summaries of GIS applications from 50 different industries.

In spite of the constant growth of theoretical and practical publications, GIS implementation in developing counties still has a character of an ad hoc approach. In this paper we identify project management methodology as the key to forcing wider GIS implementation in local governance.

The purpose of the research is through the project management methodology to propose a mechanism for optimizing regional governance model on the platform of geoinformation systems for developing country.

Object - regional public governance system. Subject - managing models of regional public governance.

The methodological basis of the study is a set of methods and techniques of project analysis (including a logical-structural matrix of project goals and results, stakeholders analysis, schedule development, budgeting, etc.), with the help of which a pilot project was performed to implement a brand-new territory management system based on GIS technology into the regional public governance (on the example of Zhytomyr oblast of Ukraine).

Except this there were also used such general and special methods of scientific research as: induction, deduction, analysis and synthesis - to substantiate the theoretical and methodological 
base of the research; historical, economic and retrospective methods - to study the periodization of decentralization reform; statistical and economical methods - to study the dynamics of economic indicators; methods of economic comparative studies and benchmarking — to compare GIS managing models of the world and find the best relevant practices; monographic method - to identify the peculiarities of the activities of regional government entities; scientific abstraction — to summarize research findings and formulate conclusions.

\section{Research results and discussion}

Our assumption was that it is possible to create an intellectual product that will enable digitalization of the processes of decision-making and control of the decisions' implementation in the territorial management on the basis of GIS technologies according to the modern world standards with the goal to disseminate our experience to neibouring Ukrainian regions and another developing countries with the similar economic and political situation. In this part of the paper we briefly summarize the way how we choosed a pilot region of Ukraine, how created a modeling concept note proposal for regional development project and what were the main results of implementation.

Our choice was the Zhytomyr region (Fig. 1) based on the following preconditions.

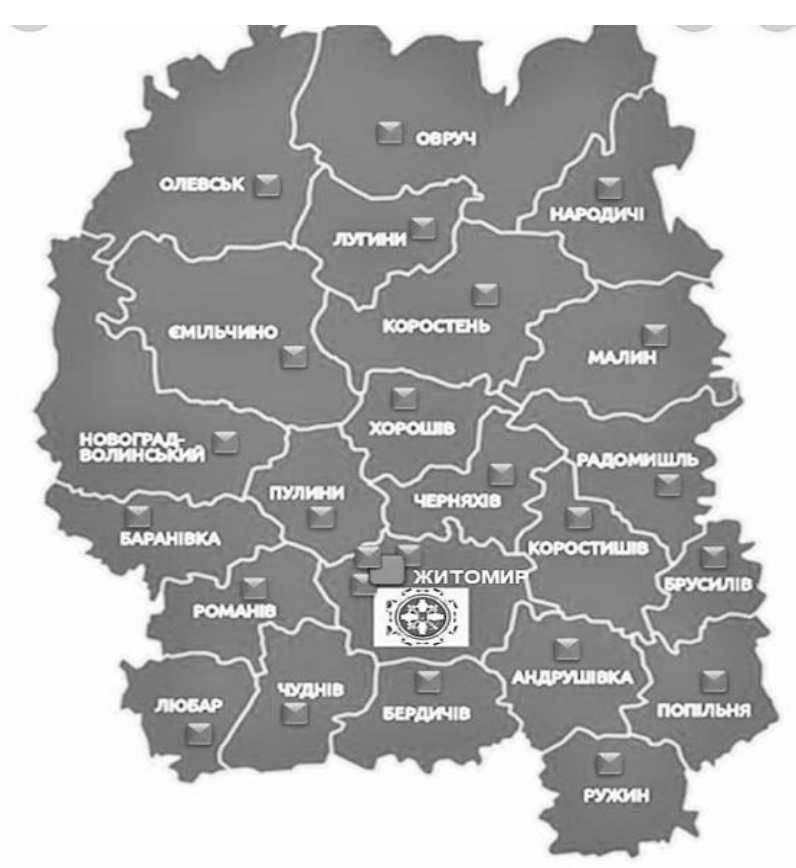

a) before decentralization

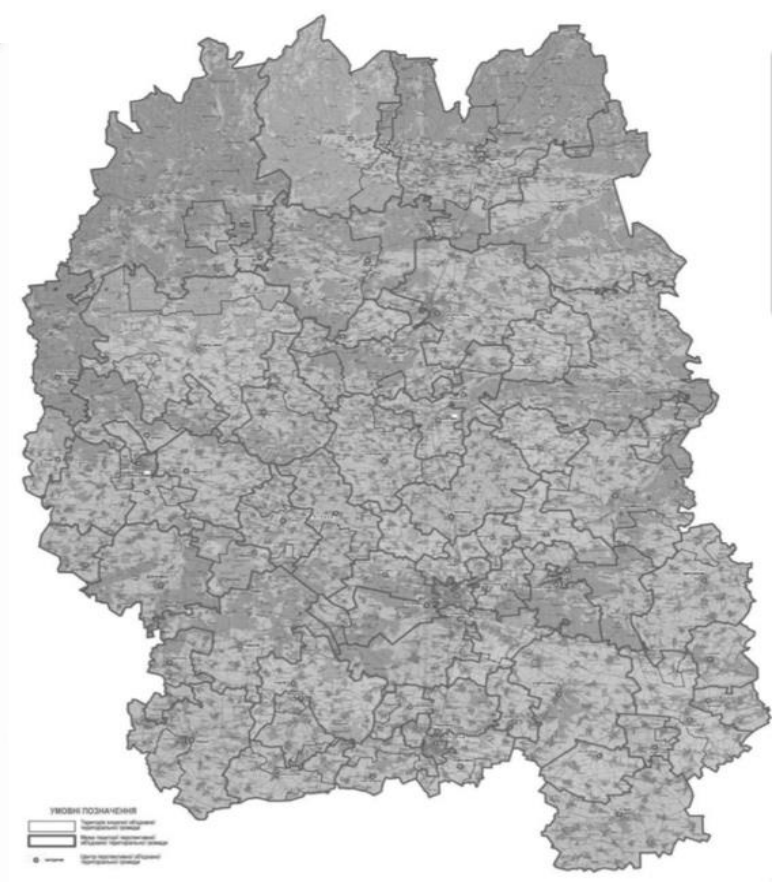

b) after decentralization

Figure 1. Administrative map of Zhytomyr region, Ukraine

Zhytomyr is a leader of decentralization processes in Ukraine (table 1) according the official statistics of forming the amalgamated communities (they already have 56 amalgamated communities from the 65 , which were planned). 
Table 1. Top-10 regions-leaders of decentralization processes in Ukraine at the beginning of the 2020 year

\begin{tabular}{|c|c|c|c|c|c|c|c|c|}
\hline \multirow[t]{2}{*}{ Region } & \multirow[t]{2}{*}{$\begin{array}{c}\text { Total } \\
\text { ranking }\end{array}$} & \multicolumn{7}{|c|}{$\begin{array}{l}\text { Rating of Ukrainian regions on the basement of indicators of economic and so- } \\
\text { cial capacity of amalgamated communities'(AC) }\end{array}$} \\
\hline & & $\begin{array}{c}\text { Popula- } \\
\text { tion of } \\
\text { AC }\end{array}$ & $\begin{array}{l}\text { Are } \\
\text { a of } \\
\text { AC }\end{array}$ & $\begin{array}{l}\text { Number } \\
\text { of hroma- } \\
\text { das, which } \\
\text { are still } \\
\text { not united }\end{array}$ & $\begin{array}{l}\text { Number } \\
\text { of dis- } \\
\text { tricts not } \\
\text { covered } \\
\text { by ac- } \\
\text { cession }\end{array}$ & $\begin{array}{l}\text { Number of } \\
\text { AC with } \\
\text { fewer than } \\
5,000 \text { peo- } \\
\text { ple of pop- } \\
\text { ulation }\end{array}$ & $\begin{array}{l}\text { Number of } \\
\text { AC with ad- } \\
\text { ministrative } \\
\text { centers in cit- } \\
\text { ies of oblast } \\
\text { significance }\end{array}$ & $\begin{array}{c}\text { Coverage } \\
\text { of pro- } \\
\text { spective } \\
\text { plans }\end{array}$ \\
\hline Zhytomyr & 1 & 5 & 3 & 3 & 1 & 11 & 3 & 3 \\
\hline Dnipropetrovsk & 2 & 2 & 2 & 2 & 1 & 16 & 7 & 1 \\
\hline Chernihiv & 3 & 4 & 4 & 4 & 1 & 14 & 2 & 4 \\
\hline Khmelnytskyi & 4 & 8 & 5 & 5 & 2 & 9 & 4 & 1 \\
\hline Zaporizhzhia & 5 & 3 & 1 & 1 & 1 & 19 & 9 & 1 \\
\hline Volyn & 6 & 10 & 6 & 6 & 1 & 12 & 6 & 1 \\
\hline Sumy & 7 & 9 & 12 & 12 & 3 & 10 & 1 & 2 \\
\hline Donetsk & 8 & 1 & 11 & 11 & 16 & 5 & 9 & 1 \\
\hline Chernivtsi & 9 & 14 & 8 & 10 & 7 & 6 & 2 & 11 \\
\hline Ternopil & 10 & 16 & 9 & 8 & 4 & 17 & 2 & 6 \\
\hline
\end{tabular}

2. Despite of the numeral local initiatives, performance indicators for the implementation of the State Strategy for Zhytomyr Oblast Development for the period up to 2020 were significantly behind the projected level (in particular, indicators of production of innovative products in total industrial output, foreign direct investment per 1 person, etc.), what makes the case more complicated, controversial and interesting for research.

3. At November 12, 2019 Zhytomyr regional council approved the Concept of the innovationspace cluster "Polissya" created on the territory of the region in the public-private partnership of the State Space Agency of Ukraine, National Center for Space Management and Testing, Zhytomyr Regional Counsil, Zhytomyr Regional State Administration, Polissia National University, Sergiy Pavlovich Korolev Zhytomyr Military Institute, Andrushivska Astronomical Observatory, Student observatory of secondary school №8 in Zhytomyr, Museum of Cosmonautics named after Sergiy Pavlovich Korolev, NGO "Noosphere" and ESRI Ukraine company. This institutional decision makes Zhytomyr oblast a suitable object for testing and approbation our hypothesis.

The aim of the project was to introduce a new standard of decision-making and control over the implementation of management decisions on regional governance by optimizing the interaction of public authorities at all levels of government with each other and with civil society entities and business organizations - through the development of a multi-level system of geo-portals at GIS platform that meets EU requirements and NATO standards.

The objectives of the project were:

1) providing central government bodies with up-to-date, verified and structured information concerning Zhytomyr region;

2) increasing the fastness and efficiency of interaction of public authorities at all levels and the quality of administrative decisions by delimiting access to information;

3) inventory of local resources;

4) creating electronic passports for community's resource potential as a first step towards the "state in a smartphone";

5) building digital map of the territory by world standards;

6) promoting inter-municipal cooperation;

7) facilitating the integration of Ukraine into the world data networks (military, meteorological, agriculture, transport and logistical, etc.); 
8) ensuring transparency and free access of citizens to the processes of forming and implementing of regional policy;

9) improving professional competence and project management capacity of regional development through the establishing of educational and research regional offices.

Target audience: all stakeholders of the local and regional development including members of territorial communities, non-governmental organizations and other civil society entities, amalgamated communities' official bodies, regional public bodies, central executive authorities, social infrastructure institutions (especially higher education organizations), etc.

The Table 2 represents the main information about our project proposal.

Table 2. Summary of the project of implementing territorial governance system based on GIS technologies

\begin{tabular}{|c|c|c|c|}
\hline Indicator & \multicolumn{3}{|c|}{ Descriptive characteristic } \\
\hline $\begin{array}{l}\text { Name of the regional development program that can be imple- } \\
\text { mented at the expense of the state regional development fund }\end{array}$ & \multicolumn{3}{|c|}{$\begin{array}{l}\text { Creation of optimization mechanism for the } \\
\text { structure of regional governance on the platform } \\
\text { of GIS in the conditions of decentralization }\end{array}$} \\
\hline $\begin{array}{l}\text { Applicant (name of the local executive authority / local self-gov- } \\
\text { ernment body) }\end{array}$ & \multicolumn{3}{|c|}{$\begin{array}{l}\text { Department of Regional Development of Zhyto- } \\
\text { myr Regional State Administration }\end{array}$} \\
\hline Thematic direction of project implementation & \multicolumn{3}{|c|}{$\begin{array}{l}\text { A draft action plan for the implementation of a } \\
\text { regional development strategy }\end{array}$} \\
\hline $\begin{array}{l}\text { The corresponding tasks from the State Development Strategy of } \\
\text { the Regions for the period up to 2020, approved by the Cabinet of } \\
\text { Ministers of Ukraine from August } 6,2014 \text { No. } 385 \text {, and from the } \\
\text { regional development strategy }\end{array}$ & \multicolumn{3}{|c|}{$\begin{array}{l}\text { State strategy task: Effective public administra- } \\
\text { tion in the field of regional development. } \\
\text { Regional strategy task: Development of territo- } \\
\text { ries for the benefit of territorial communities }\end{array}$} \\
\hline \multirow{2}{*}{$\begin{array}{l}\text { Expected project financing from the State Regional Development } \\
\text { Fund, thousand UAH }\end{array}$} & 1st year & 2nd year & Total \\
\hline & 1088.21 & 5934.258 & 16820.469 \\
\hline \multirow[t]{2}{*}{ Co-financing of the project from the local budget, thousand UAH } & 1st year & 2nd year & Total \\
\hline & 120.579 & 659.362 & 1868.941 \\
\hline
\end{tabular}

Activities within the framework of the project implementation:

- procurement of necessary equipment and development of a regional geoportal system on the basis of software (a network of geoportals in all subjects of regional administrative law as integral parts of a regional geoportal);

- introduction of a compulsory training system to support the adoption and control of implementation of GIS-based management decisions for certain categories of civil servants and local selfgovernment officials;

- creation of educational and research territorial offices at the amalgamated communities;

- development the model of regional educational space;

- informational and organizational support for training and promotional activities, drawing up memoranda of interaction;

- preparation of Community Development Strategies as a set of investment proposals in the context of the overall Regional Development Strategy;

- dissemination the successful experience of implemented projects to others region.

Table 3 represents the timing plan and final calculations for planned activities. The calculations were based on the estimations, proposed by the main stakeholders, responsible for the activities (Department of Regional Development of Zhytomyr Regional State Administration, Polissia National University, ESRI Ukraine). 
Table 3. Project implementation plan and budget for activities

\begin{tabular}{|c|c|c|c|c|c|c|}
\hline \multirow[b]{2}{*}{ Initiative } & \multicolumn{3}{|c|}{ Sources of financing, 1st year } & \multicolumn{3}{|c|}{ Sources of financing, 2nd year } \\
\hline & $\begin{array}{l}\text { State Re- } \\
\text { gional De- } \\
\text { velopment } \\
\text { Fund, thou- } \\
\text { sand UAH }\end{array}$ & $\begin{array}{l}\text { Local } \\
\text { budget }\end{array}$ & $\begin{array}{l}\text { Affili- } \\
\text { ate } \\
\text { funds }\end{array}$ & \begin{tabular}{|} 
State \\
Regional Devel- \\
opment Fund, \\
thousand \\
UAH
\end{tabular} & $\begin{array}{c}\text { Local } \\
\text { budget }\end{array}$ & $\begin{array}{l}\text { Affiliate } \\
\text { funds }\end{array}$ \\
\hline $\begin{array}{l}\text { Purchasing Computer and Periph- } \\
\text { eral Equipment for Project Partners }\end{array}$ & 3255.42 & 361.714 & - & 2377.026 & 264.114 & - \\
\hline $\begin{array}{l}\text { Purchasing Software Packages for } \\
\text { Project Partner }\end{array}$ & 3177.90 & 353.10 & - & 567.00 & 63.00 & - \\
\hline System Complexation & 476.685 & 52.965 & - & 85.05 & 9.45 & - \\
\hline Creating Local Databases & 360.00 & 40.00 & - & 585.00 & 65.00 & - \\
\hline $\begin{array}{l}\text { Formation of Geospatial Infrastruc- } \\
\text { ture. Loading Data Info Databases }\end{array}$ & 900.00 & 100.00 & - & 360.00 & 40.00 & - \\
\hline $\begin{array}{l}\text { Creating Profile Modules (applica- } \\
\text { tions) }\end{array}$ & 360.00 & 40.00 & - & 450.00 & 50.00 & - \\
\hline $\begin{array}{l}\text { Development of Regulatory Docu- } \\
\text { ments }\end{array}$ & 585.00 & 65.00 & - & 320.382 & 35.598 & - \\
\hline $\begin{array}{l}\text { Organization and Training of Pro- } \\
\text { ject Partners' Representatives }\end{array}$ & 445.500 & 49.500 & - & 445.500 & 49.500 & - \\
\hline $\begin{array}{l}\text { Creating a Roadmap for the Invest- } \\
\text { ment Projects Development using } \\
\text { GIS }\end{array}$ & 339.30 & 37.70 & - & 234.00 & 26.00 & - \\
\hline $\begin{array}{l}\text { Administration of the Hardware and } \\
\text { Software of the Servers and the } \\
\text { Network Component of the System }\end{array}$ & 756.00 & 84.00 & - & 414.00 & 46.00 & - \\
\hline $\begin{array}{l}\text { Information Campaign: Field Trips, } \\
\text { Media Content, Catering, etc. }\end{array}$ & 230.40 & 25.60 & - & 96.30 & 10.70 & - \\
\hline
\end{tabular}

Successful implementation of the project envisioned significant impact for the territory as a result of development of regional GIS tools, design and implementation of training courses for project partners' representatives, creating a complex of regulations for interactions between project partners etc. (Table 4). As sources of verification for indicators of success it was supposed to use the sites of project partners and official regional statistical data.

Table 4. Expected output of the project implementation

\begin{tabular}{|c|c|c|c|c|c|}
\hline & \multirow{2}{*}{$\begin{array}{c}\text { The values } \\
\text { of the indi- } \\
\text { Success rates of the project }\end{array}$} & \multicolumn{2}{|c|}{ Values at the end of the fiscal year (prognostic) } \\
\cline { 3 - 6 } & $\begin{array}{c}\text { beginning of } \\
\text { the project }\end{array}$ & $\begin{array}{c}\text { 1st year of } \\
\text { the project }\end{array}$ & $\begin{array}{c}\text { 2nd year of } \\
\text { the project }\end{array}$ & $\begin{array}{c}\text { 1 year after } \\
\text { the project } \\
\text { completion }\end{array}$ & $\begin{array}{c}\text { 2 year after the } \\
\text { project comple- } \\
\text { tion }\end{array}$ \\
\hline $\begin{array}{l}\text { Creating Geoportals - for Zhytomyr Re- } \\
\text { gional State Administration (10), for } \\
\text { amalgamated communities (57) }\end{array}$ & 0 & 37 & 30 & & - \\
\hline $\begin{array}{l}\text { Formation of infrastructure of basic and } \\
\text { profile geospatial data and their loading } \\
\text { into databases }\end{array}$ & 0 & 37 & 30 & & - \\
\hline
\end{tabular}


Iryna Lytvynchuk, Oleh Skydan, Olha Ivaniuk

Local Governance and Territorial Development on the basis of GIS

\begin{tabular}{|l|c|c|c|c|c|}
\hline $\begin{array}{l}\text { Development of mechanisms, instruc- } \\
\text { tions, provisions, regulations of interac- } \\
\text { tions between Project Partners }\end{array}$ & 0 & 1 & - & - & - \\
\hline $\begin{array}{l}\text { Development of a Roadmap for Partners } \\
\text { training on the basis of one of the re- } \\
\text { gional universities of the region }\end{array}$ & 0 & 1 & - & - & - \\
\hline $\begin{array}{l}\text { Developing a GIS training course cur- } \\
\text { riculum for all Project Partners }\end{array}$ & 0 & 1 & - & - & - \\
\hline $\begin{array}{l}\text { Training of representatives of partner } \\
\text { organizations (persons) }\end{array}$ & 0 & 50 & 50 & - & - \\
\hline $\begin{array}{l}\text { Developing a roadmap for creating in- } \\
\text { vestment projects for the Project Part- } \\
\text { ners with GIS tools }\end{array}$ & 0 & 1 & - & - & - \\
\hline $\begin{array}{l}\text { Development of Partner Community } \\
\text { Concepts and Projects }\end{array}$ & 0 & 10 & 20 & 30 & 30 \\
\hline
\end{tabular}

As a result of common efforts after a few months of work we tested the pilot version of Zhytomyr regional geoportal (Fig. 2) on the basis of the ArcGIS software, which was fulfilled with the next data:

1) general plans of territories, settlement map, comprehensive assessment of the territory, plan for the modern use of the territory, scheme of defense of the territory and settlements (to provide regional authorities with the most up-to-date, verified and logically structured information at local and regional level with convenient and fast search);

2) scheme of production development, scheme of agricultural development, diagram of main pipelines, scheme of the predicted state of the nature environment (to protect business from the vacuum of management decisions at the regional level in the conditions of the transition from the district administrative-territorial division to the system of amalgamated territorial communities);

3) transport desk, tourist recreation, layout of cultural heritage sites network of public services (to provide free access of citizens to truthful information on the activity of governmental and business structures, which will significantly improve the control ability of the public).

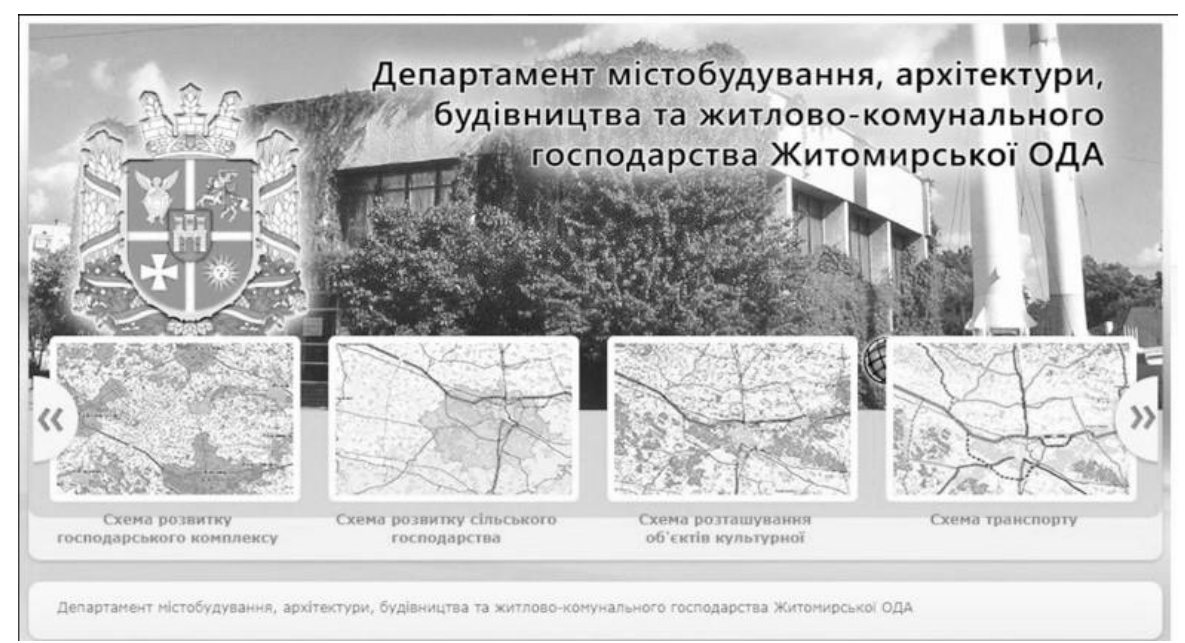

Figure 2. The home page of the Zhytomyr Regional Geoportal

Source: https://ztmbk.gov.ua/

The content of the Zhytomyr geoportal is the evidence that as a result of the project Zhytomyr region was provided by data sets, which cover all types of participatory GIS, means government-togovernment, government-to-business and government-to-citizen applications. However, the comparativistic research of case studies of existing GIS portals for different urban and rural territories shows that many topics still are not covered. For instance, among the areas which are not presented we can 
mention education, public health and public works. Our observations are performed at the Table 5.

Generally the logic of GIS implementation is consistent with the recommendations and algorithms of international structures, based on the following algorithm: 1) establishing a geospatial program (defining strategic vision, getting support from governance, appointing coordinator, developing geospatial plan); 2) maintaining data (basic geospatial datasets, metadata, licenses etc.); 3) sharing with the public (managing access to jurisdiction's geospatial data, providing feedback to users).

However, it is obvious that local government has difficulties with 'enterprise approach' (Best Practices..., 2011) to managing and promoting the geospatial data and technology (no web or desktop applications, software licenses, mobile computing, IT support services etc.), so that the available functions can be more easily consumed. This fact, in our opinion, significantly influence in the cost of GIS by attracting additional funds. For example, in the USA, the Wisconsin Land Information Program helps fund the County Land Information Office by delineating $\$ 8$ of every document recorded at the Register of Deeds Office. In Ozaukee County, that amounts to over $\$ 100,000$ per year (An Analysis of Benefits..., 2015).

Stakeholder roundtables, during which the interim results of the project were evaluated, helped to identify some GIS implementation problems, similar to those encountered in other countries. In particular, observations after conducting the pilot implementation and publishing the Geoportal of Sokółka, Poland (Medolińska, K., Gołębiowska, I., \& Karsznia, I., 2017), demonstrate common for Zhytomyr region difficulties of moderation the involvement of the authorities and government employees in the implementation of the GIS project; lack of preparation of employees of the IT department to handle GIS software; resistance of employees to the permanent changes, lack of vector data from the local authorities, preventing use of the full potential of GIS; no good practices related to the implementation of GIS in local governments. Discussing the threats, experts mentioned the rapid technological development and the absence of a strong legal framework. However, the overall assessment of the project was positive. Stakeholders accentuated on the expedience of gathering data resources in one place (including information related not only to the local objects but to data from other portals); interdepartmental cooperation for effective planning, task implementation, sharing data; optimization of decision-making processes through decreasing of uncertainty.

Table 5. Zhytomyr geoportal functions analysis

\begin{tabular}{|c|c|c|c|c|c|}
\hline $\begin{array}{l}\text { Local govern- } \\
\text { ment geoportal } \\
\text { functions }\end{array}$ & $\begin{array}{l}\text { Availability at } \\
\text { Zhytomyr geo- } \\
\text { portal (at the } \\
\text { beginning of } \\
\text { the 2020) }\end{array}$ & $\begin{array}{l}\text { Local govern- } \\
\text { ment geoportal } \\
\text { functions }\end{array}$ & $\begin{array}{l}\text { Availability at } \\
\text { Zhytomyr geo- } \\
\text { portal (at the } \\
\text { beginning of } \\
\text { the } 2020 \text { ) }\end{array}$ & $\begin{array}{c}\text { Local government } \\
\text { geoportal func- } \\
\text { tions }\end{array}$ & $\begin{array}{c}\text { Availability } \\
\text { at Zhytomyr } \\
\text { geoportal (at } \\
\text { the beginning } \\
\text { of the 2020) }\end{array}$ \\
\hline \multicolumn{2}{|c|}{ Community Development } & \multicolumn{2}{|c|}{ Economic Development } & \multicolumn{2}{|c|}{ Education } \\
\hline $\begin{array}{l}\text { - Citizen partici- } \\
\text { pation }\end{array}$ & + & $\begin{array}{l}\text { - Special district } \\
\text { assessments }\end{array}$ & + & $\begin{array}{l}\text { - School boundary } \\
\text { assignment }\end{array}$ & - \\
\hline $\begin{array}{l}\text { - Land-use analy- } \\
\text { sis }\end{array}$ & + & $\begin{array}{l}\text { - Affordable } \\
\text { housing }\end{array}$ & - & $\begin{array}{l}\text { - Facilities for edu- } \\
\text { cational manage- } \\
\text { ment }\end{array}$ & - \\
\hline $\begin{array}{l}\text { - Sustainability } \\
\text { initiatives }\end{array}$ & + & - Job creation & - & $\begin{array}{l}\text { - Classroom in- } \\
\text { struction }\end{array}$ & - \\
\hline - Zoning efforts & + & $\begin{array}{l}\text { - Business attrac- } \\
\text { tion }\end{array}$ & - & \multicolumn{2}{|c|}{ Health and Human Services } \\
\hline $\begin{array}{l}\text { - Capital im- } \\
\text { provement plan- } \\
\text { ning }\end{array}$ & - & \multicolumn{2}{|c|}{ Environment } & $\begin{array}{l}\text { - Disease outbreak } \\
\text { tracking and re- } \\
\text { sponse }\end{array}$ & - \\
\hline - $3 \mathrm{D}$ visualization & - & $\begin{array}{l}\text { - Air quality im- } \\
\text { provements }\end{array}$ & - & - Services locators & - \\
\hline \multicolumn{2}{|c|}{$\begin{array}{l}\text { Homeland Security and Emergency } \\
\text { Management }\end{array}$} & $\begin{array}{l}\text { - Environmental } \\
\text { protection }\end{array}$ & + & $\begin{array}{l}\text { - Social services } \\
\text { administration }\end{array}$ & - \\
\hline
\end{tabular}




\begin{tabular}{|c|c|c|c|c|c|}
\hline $\begin{array}{l}\text { - Infrastructure } \\
\text { protection }\end{array}$ & - & - Site remediation & - & \multicolumn{2}{|c|}{ Public Works } \\
\hline $\begin{array}{l}\text { - Natural disaster } \\
\text { mitigation and re- } \\
\text { sponse }\end{array}$ & - & $\begin{array}{l}\text { - Disaster re- } \\
\text { sponse }\end{array}$ & - & - Vehicle routing & - \\
\hline $\begin{array}{l}\text { - Evacuation } \\
\text { planning }\end{array}$ & + & $\begin{array}{l}\text { - Water manage- } \\
\text { ment }\end{array}$ & - & $\begin{array}{l}\text { - Parks manage- } \\
\text { ment }\end{array}$ & - \\
\hline $\begin{array}{l}\text { - Situational } \\
\text { awareness }\end{array}$ & - & \multicolumn{2}{|c|}{ Public Safety } & - Permitting & - \\
\hline $\begin{array}{l}\text { - Hazmat re- } \\
\text { sponse }\end{array}$ & - & - Crime analysis & - & $\begin{array}{l}\text { - Work order man- } \\
\text { agement }\end{array}$ & - \\
\hline $\begin{array}{l}\text { - Alcohol Retail- } \\
\text { ers }\end{array}$ & - & $\begin{array}{l}\text { - Deployment } \\
\text { planning }\end{array}$ & - & \multicolumn{2}{|c|}{ Transparency } \\
\hline $\begin{array}{l}\text { - Cemetery Map- } \\
\text { ping }\end{array}$ & - & $\begin{array}{l}\text { - Threat assess- } \\
\text { ment }\end{array}$ & - & $\begin{array}{l}\text { - Open Govern- } \\
\text { ment }\end{array}$ & + \\
\hline \multicolumn{2}{|c|}{ Tourism } & $\begin{array}{l}\text { - Suspicious ac- } \\
\text { tivity reporting }\end{array}$ & - & $\begin{array}{l}\text { - Citizen engage- } \\
\text { ment }\end{array}$ & - \\
\hline $\begin{array}{l}\text { - Historical Aerial } \\
\text { Photography }\end{array}$ & - & - Transportation & + & $\begin{array}{l}\text { - Citizen infor- } \\
\text { mation portals }\end{array}$ & - \\
\hline $\begin{array}{l}- \text { Recreation } \\
\text { Farmland }\end{array}$ & + & $\begin{array}{l}\text { - Demographics } \\
\text { Information }\end{array}$ & - & $\begin{array}{l}\text { - Property tax as- } \\
\text { sessment }\end{array}$ & - \\
\hline $\begin{array}{l}\text { - Elderly Facili- } \\
\text { ties }\end{array}$ & - & $\begin{array}{l}\cdot \text { Emergency } \\
\text { Management } \\
\text { Natural Areas }\end{array}$ & - & - Crowdsourcing & - \\
\hline
\end{tabular}

\section{Conclusions}

Consequently, the study confirmed the fact that GIS technologies are gradually getting into all spheres of public administration in developing countries (as Ukraine), moving from the role of a tool for solving narrow application problems to the factor of territorial development. New standard of regional governance on a basement of a GIS platform not only familiarizing all levels public authorities, civil society entities and business organizations with digitalization and simplifying decision making with a help of spatial technologies. It generates numerous additional benefits, among of which: ability to develop internal GIS datasets despite the lack of staff or budget for communities; easier and wider data access and distribution for private business, nongovernmental organizations and citizens, enhanced participation of local society in policymaking and accelerated decentralization processes; increasing external (nonresident) interest in the activities of local authorities and due to this strengthening of regional brand.

The future of regional geoportals related to tree pillars: harmonization (spatial data adjustment), versatility (flexibility in meeting the needs of various user groups), participation (changing orientation of services to make possible for users create their own designs of GIS or to complete modifications of existing ones).

\section{References}

1000 GIS Applications \& Uses - How GIS Is Changing the World (2016). - GIS Geography.-https://gisgeography.com/gis-applications-uses/ [2020 0120$]$.

A Guide for Smart Communities: Using GIS Technology for Local Government Management (2018). - ESRI. — https://icma.org/sites/default/files/18-137\%20GIS\%20e-Primer\%20Report_final.pdf [2020 0120$]$.

Albrecht, J. (2018). GIS Project Management. In: Huang, B. (Ed.) // Comprehensive Geographic Information Systems. Vol. 1: 446-477. Oxford: Elsevier. - http://dx.doi.org/10.1016/B978-0-12-409548-9.09612-3 [2020 01 20].

An Analysis of Benefits from Use of Geographic Information Systems by Ozaukee County (2015). -Ozaukee County Land Information Office, Wisconsin. - https://www.co.ozaukee.wi.us/DocumentCenter/View/5875/OzaukeeCounty-Benefits-from-Use-of-GIS?bidId= [2020 0120$]$.

Baud, I., Pfeffer, K., Sydenstricker-Neto, J., Denis, E., Scott, D., \& Minaya, L. (2016). Knowledge management 
in urban governance; building adaptive capacity through ICT-GIS-based systems in the global South // Development, Environment and Foresight. Vol. 2. No. 1: 7-22. - http://www.def-journal.eu/index.php/def/article/view/16 [2020 01 20]. Best practices for local government geospatial programs (2011). - Federal Geographic Data Committee. https://www.fgdc.gov/ngac/ngac-local-gov-gis-best-practices-paper.pdf [2020 0120$]$.

Budić, Z. (1994). Effectiveness of Geographic Information Systems in Local Planning // Journal of the American Planning Association. Vol. 60. No. 2: 244-263. - https://doi.org/10.1080/01944369408975579 [2020 0120$].$

Campbell, H. (1994). How effective are GIS in practice? A case study of British local government. // International Journal of Geographical Information Systems. Vol. $8 . \quad$ No. $3: \quad 309-325$. https://doi.org/10.1080/02693799408902002 [2020 01 20].

Carver, S., Evans, A., Kingston, R., \& Turton, I. (2001). Public Participation, GIS, and Cyberdemocracy: Evaluating on-Line Spatial Decision Support Systems // Environment and Planning B: Planning and Design. Vol. 28. No. 6: 907-921. - https://doi.org/10.1068/b2751t [2020 01 20].

Ceccato, V., \& Snickars, A. (2000). Adapting GIS technology to the needs of local planning // Environment and Planning B: Planning and Design. Vol. 27: 923-937. - https://doi.org/10.1068/b26103 [2020 0120$].$

Decentralization in Ukraine. (2019). Monitoryng protsesu detsentralizatsii ta reformuvannia mistsevogo samovriaduvannia Ministerstva rozvytku hromad ta terytorii Ukrainy 10.11.2019 (Monitoring of the process of decentralization and reform of local self-government of the Ministry of Communities and Territories of Ukraine 10.11.2019). - https://decentralization.gov.ua/news/11833 [2020 0120$].$

Decentralization in Ukraine. (2020). Monitoryng protsesu detsentralizatsii ta reformuvannia mistsevogo samovriaduvannia Ministerstva rozvytku hromad ta terytorii Ukrainy 10.01.2020 (Monitoring of the process of decentralization and reform of local self-government of the Ministry of Communities) and Territories of Ukraine 10.01.2020_. - https://decentralization.gov.ua/news/12055 [2020 01 20].

Dekolo, S., \& George, C. (2004). Implementing gis in local authorities - tips for success // Proceedings of The URISA Conference. Naveda. - https://www.researchgate.net/publication/265478286_IMPLEMENTING_GIS_IN_LOCAL_AUTHORITIES-TIPS_FOR_SUCCESS [2020 01 20].

Drummond, W., \& French, S. (2008) The Future of GIS in Planning: Converging Technologies and Diverging Interests // Journal of the American Planning Association. Vol. 74: 161-174. https://doi.org/10.1080/01944360801982146 [2020 01 20].

Elwood, S., \& Leitner, H. 1998. GIS and community-based planning: Exploring the diversity of neighborhood perspectives and needs // Cartography and Geographic Information Systems. Vol. 25. No.2: 77-88. - https://doi.org/10.1559/152304098782594553 [2020 01 20].

Eria, S., \& McMaster, R. (2017). GIS diffusion in Uganda // International Journal of Geographical Information Science. Vol. 31. No. 5: 884-906. - https://doi.org/10.1080/13658816.2016.1242131 [2020 0120$]$ ].

GIS Solutions for Urban and Regional Planning (2006). - ESRI. https://www.esri.com/library/brochures/pdfs/gis-sols-for-urban-planning.pdf [2020 0120$]$.

Heywood, D. I., Cornelius, S., \& Carver, S. (1998). An introduction to geographical information systems. - New York: Addison Wesley Longman.

Kim, M., Gwak, I., \& Koh J. (2019). The strategies of advanced local spatial data infrastructure for Seoul Metropolitan Government // International Journal of Urban Sciences. Vol. 23. No. 3: 352-368.https://doi.org/10.1080/12265934.2018.1458639 [2020 01 20].

Medolińska, K., Gołębiowska, I., \& Karsznia, I. (2017). Local GIS: development and assessment of the geoportal for local governments and local communities. Case study of a small town in Poland // Miscellanea Geographica. Vol. 21. No. 4: 160-167. - https://doi.org/10.1515/mgrsd-2017-0031 [2020 01 20].

Moura, E., \& Procopiuck, M. (2020) GIS-based spatial analysis: basic sanitation services in Parana State, Southern Brazil // Environmental Monitoring and Assessment. Vol. 192. No. 96. - https://doi.org/10.1007/s10661-020-8063-2 [2020 0120$]$.

Nedović-Budić, Z. (2000). Geographic information science implications for urban and regional planning // URISA Journal. Vol. 12, 81-93. -https://pdfs.semanticscholar.org/5d15/374050798f0c4274444bb2b793453d4a5919.pdf [2020 0120$]$.

Odendaal, N. (2003). Information and communication technology and local governance: understanding the difference between cities in developed and emerging economies // Computers, Environment and Urban Systems. Vol. 27 No. 6: 585-607. - https://www.sciencedirect.com/science/article/pii/S0198971503000164 [2020 0120$].$

Patterson, M., \& Hoalst-Pullen, N. (2009). Local Government Use of GIS in Comprehensive Planning. In: Gatrell, J., \& Jensen R. (Eds) // Planning and Socioeconomic Applications. Geotechnologies and the Environment. Vol 1: 205-220. Springer, Dordrecht

Petch, J. (2019). GIS, organisations and people: A socio-technical approach. - CRC Press.

Radil, S., \& Jiao, J. (2016). Public participatory GIS and the geography of inclusion // The Professional Geographer. Vol. 68. No. 2: 202-210. - https://doi.org/10.1080/00330124.2015.1054750 [2020 0120$].$

Ramsey, K. (2008). A call for agonism: GIS and the politics of collaboration // Environment and Planning A. Vol. 40 No. 10: 2346-2363. - https://journals.sagepub.com/doi/abs/10.1068/a4028 [2020 0120$]$. 
Sieber, R. (2006). Public Participation Geographic Information Systems: A Literature Review and Framework // Annals of the Association of American Geographers. Vol. 96 No. 3: 491-507. - https://doi.org/10.1111/j.14678306.2006.00702.x [2020 0120$]$.

Somers, R. (1991). GIS in US Local Government // Cities. Vol. 8. No. 1: 25-32. - https://doi.org/10.1016/02642751(91)90026-N [2020 01 20].

Talen, E. (2000). Bottom-Up GIS // Journal of the American Planning Association. Vol. 66. No. 3: 279-294. https://doi.org/10.1080/01944360008976107 [2020 01 20].

Thompson, M. (2016). Upside-down GIS: The future of citizen science and community participation // The Cartographic Journal. Vol. 53. No. 4: 326-334. - https://www.tandfonline.com/doi/abs/10.1080/00087041.2016.1243863 [2020 0120$]$.

Yearley, S., Cinderby, S., Forrester, J., Bailey, P., \& Rosen, P. (2003). Participatory modelling and the local governance of the politics of UK air pollution: a three-city case study // Environmental Values. Vol. 12. No. 2: $247-262$. - https://doi.org/10.3197/096327103129341315 [2020 0120$]$. 